\title{
Sublethal effects of different fungal isolates on Helicoverpa armigera (Lepidoptera: Noctuidae)
}

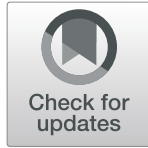

Tamires Doroteo de Souza ${ }^{*}$ D, Fabricio Oliveira Fernandes, Ariadne Costa Sanches and Ricardo Antônio Polanczyk

\begin{abstract}
Background: Broad-spectrum pesticides and Bt crops have been used against the cotton bollworm, Helicoverpa armigera (Hübner) (Lepidoptera: Noctuidae), but their effect on the environment and the development of resistance are the main limitations for these control measures. The use of mycobiopesticides is an ecofriendly and efficient alternative. Fungicides have a wide distribution and a high genetic variability, which allows their screening for more virulent isolates. Therefore, the objective of this work was to evaluate the interactions of $\mathrm{H}$. armigera larvae with Metarhizium anisopliae and Beauveria bassiana, on mortality, virulence, sublethal effects, and life table aspects.

Main body: The isolates that caused mortality rates of $\mathrm{H}$. armigera above $80 \%$ were selected for further assays. Virulence was measured by $\mathrm{LC}_{50}$ estimates, using Probit analysis to sublethal effects, and the bootstrap procedure to estimate the biological parameters: time for development, fertility, longevity, pre-ovipositional period, egg viability, and sex ratio. The H. armigera mortality rates caused by B. bassiana and M. anisopliae ranged from 45 to $100 \%$ and from 40 to 90\%, respectively. Longevity, fertility, and survival rates are affected in all treatments. The pupal weight of individuals treated with fungi was lower than in the control. Deformations were observed in $H$. armigera pupae developed from larvae treated with B. bassiana.
\end{abstract}

Conclusion: The use of sublethal concentrations of isolates of $M$. anisopliae and B. bassiana resulted in an adverse effect on the biological parameters of $\mathrm{H}$. armigera.

Keywords: Helicoverpa armigera, Metarhizium anisopliae, Beauveria bassiana, Pathogenicity, Sublethal effects, Life table

\section{Main text \\ Background}

The cotton bollworm, Helicoverpa armigera (Hübner) (Lepidoptera: Noctuidae), is one of the most important insect pests of cotton in the world. It attacks more than 200 host plants (Challa et al. 2013). Its high polyphagia, reproductive capacity, and wide geographic distribution facilitated its adaptation to different agroecosystems (Tay et al. 2013). The severity of the damages caused

\footnotetext{
* Correspondence: tamiresdoroteo@gmail.com Department of Crop Protection, College of Agricultural and Veterinary Sciences, São Paulo State University, Rod. Prof. Paulo Donato Castellane km 5, Jaboticabal, SP CEP 14884-900, Brazil
}

\section{Springer Open}

and the frequency of applications of chemical insecticide to control this pest have accelerated its resistance development and increased environmental problems (Yang et al. 2013). Thus, efficient alternatives for its control with less aggressiveness to the environment are necessary. Entomopathogenic fungi (EPF) are important to control insect pests from several orders, including lepidopterans (Lacey 2017). These microorganisms present high efficiency of control and have been used in bioinsecticide formulations due to their harmlessness to humans, the environment, and natural enemies (Jaronski et al. 2007).

(c) The Author(s). 2020 Open Access This article is licensed under a Creative Commons Attribution 4.0 International License, which permits use, sharing, adaptation, distribution and reproduction in any medium or format, as long as you give appropriate credit to the original author(s) and the source, provide a link to the Creative Commons licence, and indicate if changes were made. The images or other third party material in this article are included in the article's Creative Commons licence, unless indicated otherwise in a credit line to the material. If material is not included in the article's Creative Commons licence and your intended use is not permitted by statutory regulation or exceeds the permitted use, you will need to obtain permission directly from the copyright holder. To view a copy of this licence, visit http://creativecommons.org/licenses/by/4.0/. 
The fungi, Beauveria bassiana and Metarhizium anisopliae (Ascomycota: Hypocreales), are generalists, with a wide geographic distribution and a high frequency in soils and plants (Zimmermann 2007; Rezende et al. 2015 and Botelho et al. 2019). Selecting promising isolates to control specific insect pests is possible due to their wide distribution, high intraspecific genetic variability, and spectrum of action (Goettel et al. 2010). B. bassiana and $M$. anisopliae have been studied for controlling $H$. armigera with lethal and sublethal rates, evaluating the parameters survival rate, adult longevity, sex ratio, and fertility (Ahmad and Ansari 2013 and Jarrahi 2016).

Pest species fertility, mortality rates at different instars, and sex ratio of the population are required data to determine the pathogenicity of certain concentrations of EPF. The life table with inclusion of males increases knowledge about the population dynamics of the pests (Peroni and Hernández 2011). Therefore, interaction studies of isolates are essential to predict the effect of EPF on pest's population.

The objective of the study was to evaluate the changes in biological parameters of $H$. armigera larvae treated with different isolates of $B$. bassiana and M. anisopliae and compare the efficiency of these pathogens.

\section{Materials and methods Fungal isolates}

Twenty-three isolates of the fungi B. bassiana and $M$. anisopliae were obtained and used in the bioassays. They were isolated from the collection of EPF cultures (ARSE F-USDA) of the School of Agriculture Luiz de Queiroz (ESALQ, Piracicaba, SP, Brazil) and Biological Institute (IBCB, Campinas, SP, Brazil) (Table 1). Suspensions of each fungus used in the bioassays were prepared by scraping the conidia produced in Potato Dextrose Agar (PDA) culture medium with $0.002 \mu \mathrm{l}$ of Tween $80^{\circ}$. Each fungal suspension was subjected to serial dilutions of conidia counting in a Neubauer chamber (Alves 1998), following a concentration pattern of $10^{8}$ conidia $\mathrm{ml}^{-1}$ for each treatment.

\section{Conidia viability test}

The conidia viability test carried out as follows: a thin layer of PDA (approximately $2.0 \mathrm{ml}$ ) was placed in a plate after the solidification of the medium. Each plate received $0.1 \mathrm{ml}$ of the fungal suspension, which was prepared by each fungal isolate in $10 \mathrm{ml}$ of sterile distilled water and $0.02 \%$ Tween $80^{\circ}$. The suspensions spread, using a Drigalski loop, after flamed and properly cooled.

Table 1 Origin of entomopathogenic fungi used in the bioassays

\begin{tabular}{|c|c|c|c|}
\hline Isolates & Pathogens & Origin & Host \\
\hline ARSEF 3293 & Metarhizium anisopliae & México, MEX & Spodoptera frugiperda \\
\hline ARSEF 1080 & " " & Gainesville, USA & Helicoverpa zea \\
\hline ESALQ 114 & $" \prime \prime$ & Goiânia, GO & Mahanarva posticata \\
\hline ESALQ 1051 & " " & Porto Alegre, RS & Solenopsis \\
\hline ESALQ 860 & " " & Piracicaba, SP & Macrospis sp. \\
\hline ESALQ 935 & " " & Itabúna, BA & Diatraea saccharalis \\
\hline IBCB 418 & " " & Iporanga, SP & Soil - Atlantic Forest \\
\hline IBCB 383 & " " & Araras, SP & Mahanarva fimbriolata \\
\hline IBCB 425 & $" \prime \prime$ & Iporanga, SP & Caterpillar \\
\hline IBCB 364 & " " & Córrego Rico, SP & Soil \\
\hline ARSEF 1149 & Beauveria bassiana & Córdoba, ARG & Helicoverpa armigera \\
\hline ARSEF 1788 & " " & Spain, ES & Helicoverpa virescens \\
\hline ESALQ 986 & " " & Piracicaba, SP & Blatella germanica \\
\hline ESALQ 1289 & " " & Caçú, GO & Leptopharsa heveae \\
\hline ESALQ 1075 & " " & Arapongas, PR & Soil \\
\hline ESALQ 480 & " " & Cuiabá, MT & Solenopsis invicta \\
\hline ESALQ 1288 & " " & Pontes e Lacerda, MT & Rhynchophorus palmarum \\
\hline IBCB 36 & " " & S. J. do Rio Pardo, SP & Hypothenemus hampei \\
\hline IBCB 170 & " " & Goiânia, GO & Cosmopolites sp. \\
\hline IBCB 38 & " " & Araras, SP & Cosmopolites sordidus \\
\hline IBCB 35 & " " & Cruz das Almas, BA & Cosmopolites sordidus \\
\hline IBCB 241 & " " & Pindamonhangaba, SP & Oryzophagus oryzae \\
\hline IBCB 1363 & " " & Pariquera-Açu, SP & Soil - rubber tree plantation \\
\hline
\end{tabular}


The plates were then kept in a greenhouse at $25 \pm 2{ }^{\circ} \mathrm{C}$ and 12 -h photophase for $24 \mathrm{~h}$. The plates were examined under an optical microscope with $\times 400$ magnification for counting of 100 conidia, germinated and nongerminated, establishing their proportion.

\section{Helicoverpa armigera mortality test}

Second-instar larvae of $H$. armigera were used for mortality bioassays. The population of the pest was at the 5th generation. The trials consisted of 23 treatments, 10 of which were isolates from $M$. anisopliae, 13 from $B$. bassiana, and a control. Two hundred caterpillars were used in each treatment. They are placed in polyethylene containers $(18 \times 30 \mathrm{~mm})$, under an artificial diet (Greene et al. 1976), and then inoculated with $0.2 \mu \mathrm{l}$, using a 10$\mu \mathrm{l}$ pipette. The same procedure was used at the control, but replacing the fungal suspension with distilled water plus $0.02\left(\mathrm{v} \mathrm{v}^{-1}\right)$ of Tween $80^{\circ}$. The plastic containers with the insects were closed and kept in an airconditioned room $\left(25^{\circ} \mathrm{C}\right.$, RH of $70 \pm 10 \%$, and photophase of $12 \mathrm{~h}$ ). Mortality evaluations started 3 days' post inoculation, considering the total number of dead insects at the end of 7 days. The caterpillars were identified as dead when presented no movement to the touch of a soft bristle brush. The death of the insects due to the pathogen was confirmed as follows: the insects were washed by $70 \%$ alcohol for $10 \mathrm{~s}$, rinsed in distilled water for $20 \mathrm{~s}$ for external decontamination, placed in plates, and left in a wet chamber for 15 days. This made it possible to observe the extrusion of the pathogen, confirming the infection. The isolates that caused deaths of $H$. armigera above $80 \%$ up to the 7 th day of evaluation were selected for the subsequent stages of the study.

\section{Lethal concentration ( $L C_{50}$ ) of M. anisopliae and B. bassiana for $\mathrm{H}$. armigera caterpillars}

Mean lethal concentration $\left(\mathrm{LC}_{50}\right)$ was estimated using 2nd-instar $H$. armigera caterpillars that were exposed to 7 concentrations $\left(10^{3}, 10^{4}, 10^{5}, 10^{6}, 10^{7}, 10^{8}, 10^{9}\right.$ conidia $\mathrm{ml}^{-1}$ ) of isolates previously selected in the mortality tests. One hundred caterpillars/treatment were used. The methodology for these bioassays, storage, and evaluation were the same as those used in the mortality tests.

\section{Evaluation of sublethal effects}

Fifty caterpillars that survived the exposure to $\mathrm{LC}_{50}$ concentrations of the most promising isolates (B. bassiana ARSEF 1149, ARSEF 1788, ESALQ 986, ESALQ 1288, IBCB 36, IBCB 170) (M. anisopliae ESALQ 860, ESALQ 1051) were monitored daily to assess the biological parameters: instar duration (days), caterpillar weight $(\mathrm{mg})$, pupal weight (mg), sex ratio, fecundity, egg viability (\%), and male and female adult longevity.
The effects of different treatments on caterpillar, prepupa, and pupa weights were evaluated by weighing them on an analytical balance (SHIMADZU-ATY224.) at the 7th day. Sexing the pupae was carried out according to the observations of the anal and genital openings, according to Zenker et al. (2007), with the aid of a magnifying glass (ZEIZZ-STEMI $508^{\circ}$ ). The males were separated from females, and couples were formed to estimate the adult pre-ovipositional period (APOP) and total ovipositional period (TPOP). The formed couples were kept at the same conditions as they reared. Ovipositional period and longevity were recorded daily. Raw data of time for development, survival, daily fertility, and male and female longevity were used for the analysis of biological variables of $H$. armigera and development of the life table. All tested individuals were considered for these evaluations, including those who died during the development of immature stages (Chi and Liu 1985 and Chi 1988). Parameters of intrinsic population growth rate $(r)$, finite population growth rate $(\lambda)$, net reproduction rate $\left(R_{\mathrm{o}}\right)$, average generation duration $(T)$, and gross reproduction rate (GRR) were estimated by the Chi and Liu's methodology (1985), using the equations:

$$
\begin{aligned}
& \sum_{X=0}^{\infty} e^{-r(x+1)} l_{x} m_{x}=1 \\
& l x=\sum_{f=1}^{\beta} S x j \\
& m x=\frac{\sum_{j=1}^{\beta} S x j f x j}{\sum_{j=1}^{\beta} S x j}
\end{aligned}
$$

where $\beta$ is the number of life stages; $s x j$ is the agespecific survival rate, considering the difference and standard deviation; $l x$ is the age-specific survival rate; $f x j$ is the age-specific fertility of the stage; and $m x$ is the age-specific fertility.

\section{Statistical analysis}

A completely randomized design with 24 treatments and 200 replications was used to select the isolates; each caterpillar was a replication. Statistical analysis was performed using the SAS program (University 2002); when the means were significant, they were compared by the Tukey test at $5 \%$ probability. The mortality data found for the different concentrations were subjected to Probit analysis, using the POLO PC Software (Leora-software 1987) to estimate the $\mathrm{LC}_{50}$.

Regarding the sublethal effects, the bootstrap procedure was used to estimate the variations, means, and standard error of the biological parameters: time for 
development, fertility, and longevity, using 100,000 bootstraps. The parameters of the $H$. armigera populations under fungal treatments and the control were compared by the paired bootstrap test $(p<0.05)$, based on the differences in confidence interval $(\mathrm{CI}=95 \%)$ using the TWOSEX-MS-Chart program (Chi 2016). Hierarchical cluster analysis was used, with the Euclidean dissimilarity measured by the coefficient similarities. Ward's clustering method was used to identify the similarity between groups. Non-hierarchical cluster analysis was used by the K-means method, with $k$ corresponding to the number of groups indicated in the hierarchical cluster analysis. The data of the variables were processed in the $\mathrm{R}$ program ( $\mathrm{R}$ Core Team, 2018).

\section{Results and discussion Mortality rates}

Mortality rates of 2nd-instar $H$. armigera caterpillars caused by the isolates of $M$. anisopliae and B. bassiana were different. The highest means were found at the treatments of IBCB 425 and ESALQ 860 for M. anisopliae, and IBCB 1363 and IBCB 36 of B. bassiana (Fig. 1 ). The number of highly virulent isolates against $H$. armigera was high at the fungus $B$. bassiana, corroborating the results of Hassani (2000), who tested the virulence of the fungus $B$. bassiana against $H$. armigera and Spodoptera littoralis caterpillars and found that several isolates of $B$. bassiana were highly virulent against noctuid species.

\section{Conidial viability}

Conidial viability of the isolates ranged $42.0-98.0 \%$ at the concentration between $1 \times 10^{2}$ and $1 \times 10^{8}$, respectively. The isolates ARSEF 1149, ESALQ 1288, IBCB 36, IBCB 170, and IBCB 1363 of the B. bassiana fungus presented a high virulence and the highest numbers of viable conidia. The isolates ESALQ 860, ESALQ 1051, and IBCB 425 of $M$. anisopliae fungus had the highest number of viable conidia, differing from the other isolates, presenting the same virulence in the mortality test (Fig. 1). The 8 isolates that caused deaths of $H$. armigera above $80 \%$ were used in the tests to estimate $\mathrm{LC}_{50}$.

\section{$L C_{50}$ estimates (Table 2)}

\section{H. armigera longevity and fecundity}

Ovipositional period was affected in $2 M$. anisopliae isolates-ESALQ 860 (3.59 days) and ESALQ $10.51 \quad(4.2$ days). The control presented 5.2 days, but with nonsignificant difference (Tables 3 and 4), as shown by the paired bootstrap method. Total time for development in the control (46.66 days) was shorter than that at the treatments ESALQ 860 (48.88 days) and ESALQ 1051 (58.8 days), but did not differ from that of the isolate IBCB 425
(47.7 days). A high susceptibility of $H$. armigera larvae to $B$. bassiana isolates was found and also observed by Nguyen et al. (2007) and Kalvnadi et al. (2018). However, the results of larval developmental period differed from those presented by Nguyen et al. (2007).

The total pre-ovipositional period (TPOP) in the treatments of ESALQ 860 and ESALQ 1051 was significantly longer than that in the control (38.52 days), but did not differ from that of the IBCB 425 treatment. The adult pre-ovipositional period (APOP) in the treatments was similar to that in the control. The average fertility of females in all treatments was lower than in the control. The lowest egg viability was found at the isolate $\mathrm{IBCB}$ 425 (60.14\%) (Table 3).

The ovipositional duration of caterpillars exposed to $B$. bassiana isolates was different from that in the control (5.2 days) (Table 4), but similar to those of the other isolates. The developmental periods of the larvae and pupae of the isolates were different and were affected in all treatments than in the control. Strategies to avoid or overcome the actions of the pathogens are different. Each host population evolves and presents the different immune responses ( $\mathrm{Lu}$ et al. 2016). The isolates may have intrinsic characteristics, which related to virulence. One of these characteristics is the production of extracellular enzymes; the production of enzymes can be different depending on the isolate and present temporal variations (Wang et al. 2009).

The maintenance of this virulence above the levels of the enzyme production may also be related to the genetic diversity of these fungi, which may be influenced by the habitat in which each isolate was obtained (Mora et al. 2016). A research comparing the location and isolation method showed that fungi isolated from soil resulted to a high mortality rate of $H$. armigera caterpillars (Kalvnadi et al. 2018). In the present study, the highest virulence was found for caterpillars exposed to isolates from soil; the isolate IBCB 1363, for example, was isolated from the soil of a rubber tree plantation. However, $M$. anisopliae isolates showed non-effect of the habitat.

Adult longevity is affected by the treatments of both sexes. It was shorter at some isolates and longer in others than the control (45.00 for females and 48.07 for males). The female longevity decreased at $B$. bassiana isolates, consistent with the results of Wu et al. (2014), and increased at $M$. anisopliae isolates, differing from the results found by Jarrahi and Safavi (2016). Longevity was low in 3 treatments IBCB 36 (35.16 days), IBCB 170 (29.46 days), and IBCB 1363 (42.78 days), differing significantly from the control (46.66 days). The isolates ARSEF 1149 (47.72 days) and ESALQ 1288 (47.08 days) did not differ from the control (Table 4). TPOP was affected by the most treatments; it was short at the isolate IBCB 36 (30.00), long at the isolates ESALQ 1288 


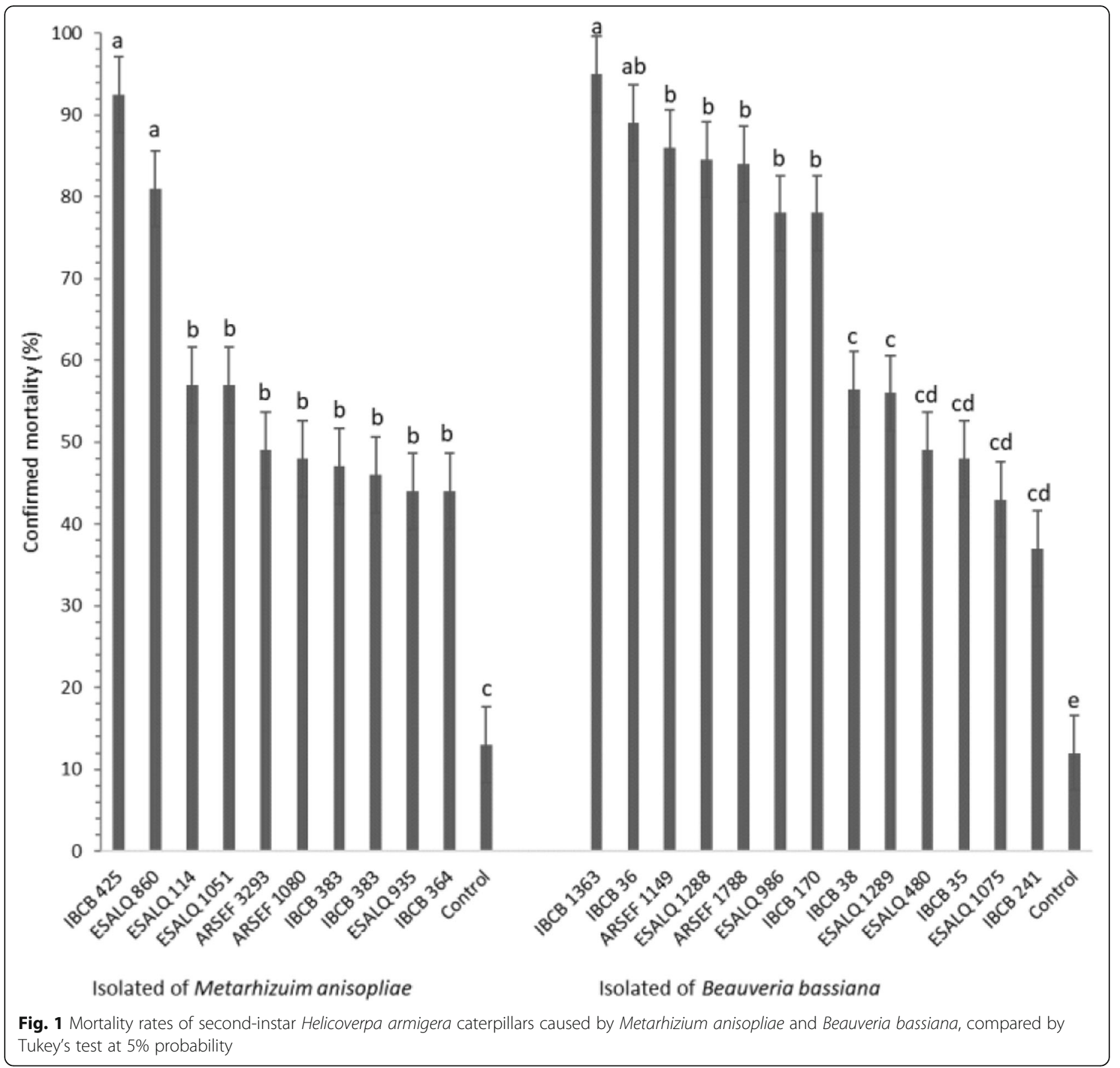

(48.88), and similar at the isolates IBCB 170 (40.36), IBCB 1363 (37.53), and ARSEF 1149 (37.45), when compared to the control (38.52).

The APOP in the control was 2.70 days, similar to those of the isolates ARSEF 1149 (2.45), IBCB 170 (2.36), and IBCB 1363 (2.53). The APOP of the ESALQ 1288 (3.44) and IBCB 36 (3.00) was significantly different from those of the other isolates. The average fertility of females in all treatments was lower than that in the control (470.83), but did not differ from each other at the isolates IBCB 1363 (328.27), ARSEF 1149 (221.23), ESAL Q 1288 (338.12), and IBCB 1363 (328.27). The egg viability was low, mainly at the isolates IBCB 1363 (75.24\%) (Table 4).
Jarrahi and Safavi (2016) found different results than Arthurs and Thomas (2000), who reported that the adult pre-ovipositional period and total ovipositional period extended in $H$. armigera at $M$. anisopliae. The egg viability of females treated with the isolates was low, as found by Kalvnadi et al. (2018); however, it differed from the results of Arthurs and Thomas (2000), who found no reduction in fertility of adults treated with $M$. anisopliae.

\section{Grouping of parameters}

Complementing the results of the bootstrap analysis, hierarchical and non-hierarchical classifications were performed for each fungal isolate. The hierarchical 
Table 2 Estimates of $\mathrm{LC}_{50}$ of Beauveria bassiana and Metarhizium anisopliae isolates for second-instar Helicoverpa armigera larvae, using the Polo-PC program

\begin{tabular}{|c|c|c|c|c|}
\hline Treatments & $\mathrm{LC}_{50}$ (conidia $\mathrm{mL}^{-1}$ ) & Slope \pm SE & $N$ & $x^{2}$ \\
\hline \multicolumn{5}{|c|}{ Beauveria bassiana } \\
\hline ARSEF 1149 & $1.4 \times 10^{6}\left(5.8 \times 10^{5}-8.1 \times 10^{6}\right)$ & $0.36 \pm 0.05$ & 100 & 8.39 \\
\hline ESALQ 1288 & $1.5 \times 10^{5}\left(3.3 \times 10^{4}-5.6 \times 10^{6}\right)$ & $0.46 \pm 0.05$ & 100 & 3.88 \\
\hline IBCB 36 & $2.9 \times 10^{5}\left(1.8 \times 10^{4}-7.1 \times 10^{6}\right)$ & $0.55 \pm 0.05$ & 100 & 2.99 \\
\hline IBCB 170 & $5.4 \times 10^{4}\left(2.8 \times 10^{3}-5.1 \times 10^{6}\right)$ & $0.29 \pm 0.05$ & 100 & 6.26 \\
\hline IBCB 1363 & $4.5 \times 10^{4}\left(2.3 \times 10^{3}-8.3 \times 10^{6}\right)$ & $0.25 \pm 0.05$ & 100 & 1.75 \\
\hline \multicolumn{5}{|c|}{ Metarhizium anisopliae } \\
\hline IBCB 425 & $6.8 \times 10^{5}\left(1.4 \times 10^{4}-2.7 \times 10^{7}\right)$ & $0.30 \pm 0.05$ & 100 & 7.2 \\
\hline ESALQ 860 & $7.8 \times 10^{6}\left(1.8 \times 10^{6}-3.7 \times 10^{7}\right)$ & $0.22 \pm 0.05$ & 100 & 9.25 \\
\hline ESALQ 1051 & $5.6 \times 10^{6}\left(2.1 \times 10^{7}-1.4 \times 10^{8}\right)$ & $0.23 \pm 0.05$ & 100 & 4.68 \\
\hline
\end{tabular}

$N$ number of caterpillars tested, $X^{2}$ chi-squared value, $L C_{50}$ lethal concentration, total conidia $\mathrm{ml}^{-1}$

cluster analysis, represented by a dendrogram, formed 4 groups: group 1 was formed by the ESALQ 1051 isolate, which was characterized by a lower mortality rate, and greater caterpillar longevity and pupa and total preovipositional periods. Group 2 was formed by IBCB 36, characterized by a low egg, pupa, caterpillar, fecundity, and oviposition. Group 3 was formed by ESALQ 1288 and IBCB 425, and group 4 was formed by ARSEF 1149, IBCB 1363, ESALQ 860, and IBCB 170, characterized by average values for all parameters (Figs. 2 and 3). The results described were confirmed by the clustering analysis (Figs. 2 and 3); groups were formed despite the isolates had different characteristics. The differences among isolates tend to be lower when considering all parameters of the sublethal effect, promoting an effective control for H. armigera.

\section{Principal component analysis}

The groups obtained in the previous analysis were confirmed by subjecting the results to principal component analysis (Fig. 4). The eigenvalues of the principal components (PC) PC1 and PC2 explained 70\% of the response variation of $H$. armigera caterpillars to the exposure to fungal isolates. Therefore, the total amount of information contained in the evaluated parameters formed 4 distinct groups, which were similar to those observed in the hierarchical cluster analysis. PC1 explained $45.45 \%$ of the variance (eigenvalue of 4.54); the parameters with greater discriminatory power in $\mathrm{PC} 1$ were BAT $(0.76)$, LOGOV (-0.65), LOGLA - 0.78), PUPA $(-0.86)$, LOGTO (-0.95), and TPOP (-0.88). PC2 explained $24.51 \%$ of the variance (eigenvalue of 2.45 ); the parameters with the greatest discriminatory power were PRPU (0.68), FECU (0.90), and OVI (0.69). The biplot graph (Fig. 4) shows the distribution of lethal and sublethal parameters of $H$. armigera caterpillars exposed to fungal isolates. The figure shows the parameters that best discriminate each isolate.

The positive correlations discriminated the isolates at the right of PC1 (IBCB 425, ESALQ 1288, IBCB 1363, and IBCB 36), and the negative correlation discriminated the isolates at the left of PC1 (ESALQ 1051, ESALQ 860, ARSEF 1149, and IBCB 170) (Fig. 4). The variables with positive correlation discriminated the isolates in the upper part of PC2 (IBCB 425 and ESALQ 1288), and the

Table 3 Developmental periods (days) of different stages, longevity, fecundity, pre-ovipositional, and total ovipositional period of Helicoverpa armigera caterpillars infected with different isolates of Metarhizium anisopliae, and a control (untreated)

\begin{tabular}{|c|c|c|c|c|}
\hline \multirow[t]{2}{*}{ Parameters } & \multicolumn{4}{|c|}{ Treatment with Metarhizium anisopliae } \\
\hline & IBCB 425 & ESALQ 860 & ESALQ 1051 & Control \\
\hline Egg (days) & $3.00 \pm 0.00 a$ & $3.00 \pm 0.00 \mathrm{a}$ & $3.00 \pm 0.00 \mathrm{a}$ & $2.89 \pm 0.00 a$ \\
\hline Caterpillars (days) & $9.00 \pm 0.00 \mathrm{~d}$ & $14.7 \pm 0.36 c$ & $24.36 \pm 0.16 a$ & $17.00 \pm 0.00 \mathrm{~b}$ \\
\hline Pre-Pupa (days) & $10.39 \pm 0.12 a$ & $5.92 \pm 0.16 b$ & $5.26 \pm 0.41 b$ & $2.00 \pm 0.00 c$ \\
\hline Pupa (days) & $16.00 \pm 0.00 \mathrm{~b}$ & $25.26 \pm 0.22 \mathrm{a}$ & $25.04 \pm 0.22 a$ & $15.00 \pm 0.25 b$ \\
\hline Adult female longevity (days) & $47.52 \pm 0.73 c$ & $53.05 \pm 0.69 b$ & $63.93 \pm 0.61 \mathrm{a}$ & $45.00 \pm 0.72 c$ \\
\hline Adult male longevity (days) & $51.64 \pm 0.36 c$ & $60.71 \pm 0.74 b$ & $65.42 \pm 0.46 a$ & $48.07 \pm 0.39 c$ \\
\hline Total Longevity (days) & $47.7 \pm 1.09 \mathrm{bc}$ & $48.88 \pm 0.70 b$ & $57.78 \pm 0.19 a$ & $46.66 \pm 0.44 c$ \\
\hline APOP (days) & $2.71 \pm 0.12 \mathrm{a}$ & $2.41 \pm 0.10 a$ & $2.53 \pm 0.13 \mathrm{a}$ & $2.70 \pm 0.26 a$ \\
\hline TPOP (days) & $40.71 \pm 0.12 c$ & $48.32 \pm 0.25 b$ & $58.8 \pm 0.34 a$ & $38.52 \pm 0.58 c$ \\
\hline Fertility (egg/F female) & $411.52 \pm 46.65 b$ & $289.18 \pm 21.42 \mathrm{~d}$ & $308.27 \pm 23.67 c$ & $470.83 \pm 24.5 a$ \\
\hline Oviposition in days & $5.2 \pm 0.51 \mathrm{a}$ & $3.59 \pm 0.23 b$ & $4.2 \pm 0.42 b$ & $5.2 \pm 0.34 \mathrm{a}$ \\
\hline
\end{tabular}

$A P O P$ adult pre-oviposition period, TPOP total pre-oviposition period-both calculated using females that produced fertile eggs. Average oviposition days were calculated for days when the number of eggs laid was greater than zero. Standard errors were estimated using 100,000 bootstraps and compared using the paired bootstrap test based on the differences in confidence intervals. Means followed by different letters in the rows are significantly different $(p<0.05)$ by the paired bootstrap test 
Table 4 Developmental periods (days) of different stages, longevity, fecundity, pre-ovipositional, and total ovipositional period of Helicoverpa armigera caterpillars infected with different isolates of Beauveria bassiana, and a control (untreated)

\begin{tabular}{|c|c|c|c|c|c|c|}
\hline \multirow[t]{2}{*}{ Parameters } & \multicolumn{6}{|c|}{ Treatment with Beauveria bassiana } \\
\hline & ARSEF 1149 & ESALQ 1288 & IBCB 36 & IBCB 170 & IBCB 1363 & Control \\
\hline Egg (days) & $3.00 \pm 0.00 \mathrm{a}$ & $3.00 \pm 0.00 \mathrm{a}$ & $2.90 \pm 0.00 \mathrm{a}$ & $2.95 \pm 0.00 \mathrm{a}$ & $3.00 \pm 0.00 \mathrm{a}$ & $2.89 \pm 0.00 \mathrm{a}$ \\
\hline Caterpillars (days) & $13.88 \pm 0.16 b$ & $8.2 \pm 0.21 c$ & $5.76 \pm 0.14 d$ & $9.00 \pm 0.00 c$ & $15.00 \pm 0.00 \mathrm{ab}$ & $17.00 \pm 0.00 \mathrm{a}$ \\
\hline Pre-Pupa (days) & $2.6 \pm 0.22 b$ & $8.2 \pm 0.21 \mathrm{a}$ & $8.71 \pm 0.14 a$ & $2.64 \pm 0.14 b$ & $3.32 \pm 0.07 c$ & $2.00 \pm 0.00 b$ \\
\hline Pupa (days) & $16.24 \pm 0.06 b$ & $16.56 \pm 0.41 b$ & $11.00 \pm 0.00 \mathrm{~d}$ & $23.45 \pm 0.19 a$ & $15.35 \pm 0.28 c$ & $15.00 \pm 0.25 c$ \\
\hline Adult female longevity (days) & $46.00 \pm 0.32 \mathrm{a}$ & $41.29 \pm 0.92 b$ & $34.43 \pm 0.20 c$ & $45.27 \pm 0.27 a$ & $42.6 \pm 0.4 b$ & $45.00 \pm 0.72 \mathrm{a}$ \\
\hline Adult male longevity (days) & $49.07 \pm 0.37 a b$ & $50.06 \pm 0.88 a$ & $37.81 \pm 0.49 c$ & $47.18 \pm 0.42 b$ & $48.56 \pm 0.34 b$ & $48.07 \pm 0.39 b$ \\
\hline Total Longevity (days) & $47.72 \pm 0.32 \mathrm{a}$ & $47.08 \pm 0.92 \mathrm{a}$ & $35.16 \pm 0.86 c$ & $29.46 \pm 2.13 d$ & $42.78 \pm 0.67 b$ & $46.66 \pm 0.44 a$ \\
\hline APOP (days) & $2.45 \pm 0.19 b$ & $3.44 \pm 0.16 a$ & $3 \pm 0.0 \mathrm{a}$ & $2.36 \pm 0.15 b$ & $2.53 \pm 0.13 b$ & $2.70 \pm 0.26 b$ \\
\hline TPOP (days) & $37.45 \pm 0.19 b$ & $48.88 \pm 0.35 a$ & $30 \pm 0.0 d$ & $40.36 \pm 0.15 b$ & $37.53 \pm 0.12 b$ & $38.52 \pm 0.58 b c$ \\
\hline Fertility (egg/ $F_{1}$ female) & $221.23 \pm 7.35 d$ & $338.12 \pm 31.86 b$ & $250.05 \pm 25.1 \mathrm{~d}$ & $289.00 \pm 45.07 c$ & $328.27 \pm 44.39 b$ & $470.83 \pm 24.5 a$ \\
\hline Oviposition in days & $4.18 \pm 0.17 b$ & $3.72 \pm 0.23 c$ & $3.14 \pm 0.30 c$ & $3.90 \pm 0.31 b c$ & $4.06 \pm 0.31 b$ & $5.2 \pm 0.34 \mathrm{a}$ \\
\hline
\end{tabular}

$A P O P$ adult pre-oviposition period, TPOP total pre-oviposition period-both calculated using females that produced fertile eggs. Average oviposition days were calculated for days when the number of eggs laid was greater than zero. Standard errors were estimated using 100,000 bootstraps and compared using the paired bootstrap test based on the differences in confidence intervals. Means followed by different letters in the rows are significantly different ( $p<0.05$ ) by the paired bootstrap test

variables with negative correlation discriminated the isolates in the lowest part of PC2 (ESALQ 1051, ESALQ 860, ARSEF 1149, IBCB 170, IBCB 1363, and IBCB 36). According to the results for the variables of the isolates, the isolates IBCB 425 and ESALQ 1288 potentially had a great pre-pupa weight, adult pre-ovipositional period, and mortality, and the isolates ESALQ 1051, ESALQ 860, ARSEF 1149, and IBCB 170 had a high pupal weight and caterpillar longevity.

\section{Sex ratio and caterpillar and pupa weights Effect of B. bassiana on biological parameters of $H$. armigera}

The weight of caterpillars after 10 days of exposure to the treatments was lower than that in the control, with differences among treatments. The pre-pupal

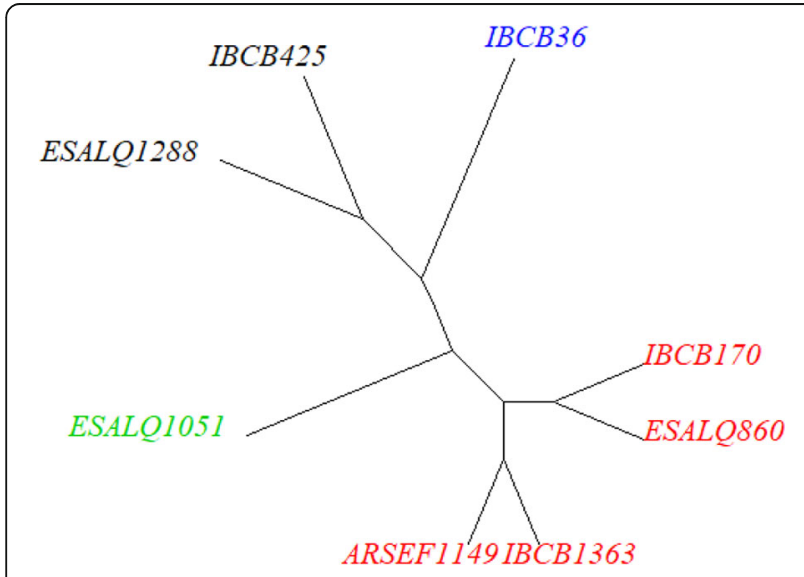

Fig. 2 Dendrogram of the hierarchical cluster analysis for the ordering of fungal isolates and pupal weights of the isolate IBCB 1363 were affected, with consequent abnormal pupae and defective adults (Fig. 5).

Fungi act via tegument, which is an advantage over other groups of pathogens that only enter the insects orally. This contact action is due to the secreting of a series of compounds, including bassianin, bassiacridin, oosporeins, cyclosporine, and destruxins (Molnar et al. 2010; Wang et al. 2010 and Gibson et al. 2014), which were dependent on the specificity of the host and can suppress their immune response (Amiri-Besheli et al. 2000).

The exoskeleton and digestive tract of insects are barriers that can be broken and trigger several cellular and hormonal mechanisms, resulting in an immune response (Levy et al. 2004). During these responses, insects begin to lose lipids and proteins that are essential to complete their cycle (Qu and Wang 2018), explaining their weight loss at the pupal stage and the non-emergence of adults found in the present study.

Kaur et al. (2011) reported morphological abnormalities in Spodoptera litura, using EPF. Most caterpillars treated with $B$. bassiana isolates were unable to complete their larval phase, and extending this stage and early forming pupae. This is explained as the actions of enzymes, and the insects' immune system, which accelerate the molting process, reducing the production of youth hormone and maintaining the production of ecdysone, which induce the ecdysis process $(\mathrm{Qu}$ and Wang 2018). The concentrations of these hormones in the hemolymph determine the completion of metamorphosis and the reproductive process of insects, which may also explain the decrease in fertility of adults treated 


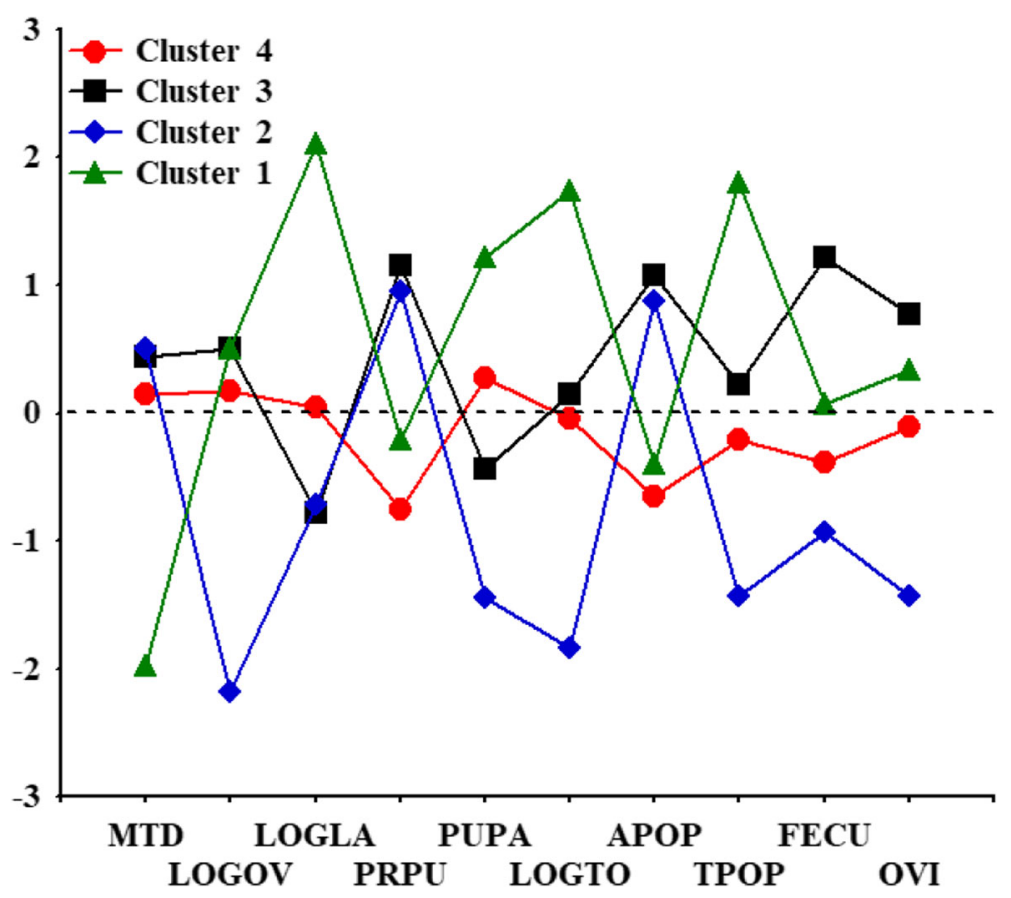

Fig. 3 Non-hierarchical cluster analysis (K-means) for the ordering of fungal isolates. Mortality (MTD), egg stage duration (LOGOV), caterpillar longevity (LOGLA), pre-pupa longevity (PRPU), pupa stage duration (PUPA), total longevity (LOGTO), adult pre-oviposition period (APOP), total preoviposition period (TPOP), fertility (FECU), oviposition (OVI)

with the isolates when compared to the control (Rohlfs and Churchill 2011).

Survival decreased considerably at the pupal stage, i.e., surviving caterpillars reached the pupal stage with a decrease weight and morphological malformations that caused their death (Fig. 5). These morphological deformations are explained by the insect defense system, which is composed of structural barriers and active responses against external elements that reach the hemocoel, such as EPF (Renwrantz 1986). The sex ratio is not affected by any of the treatments (Table 5).

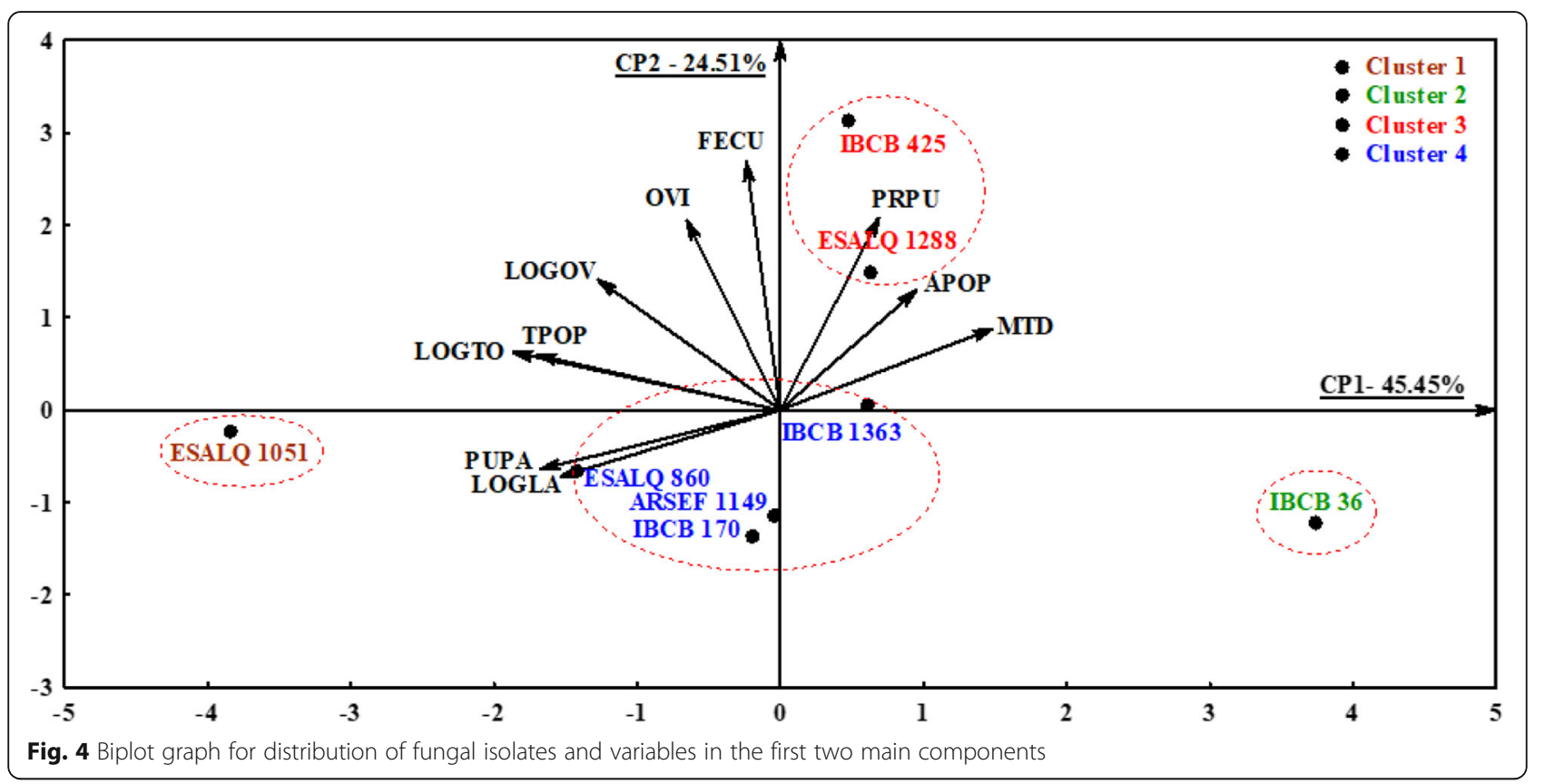



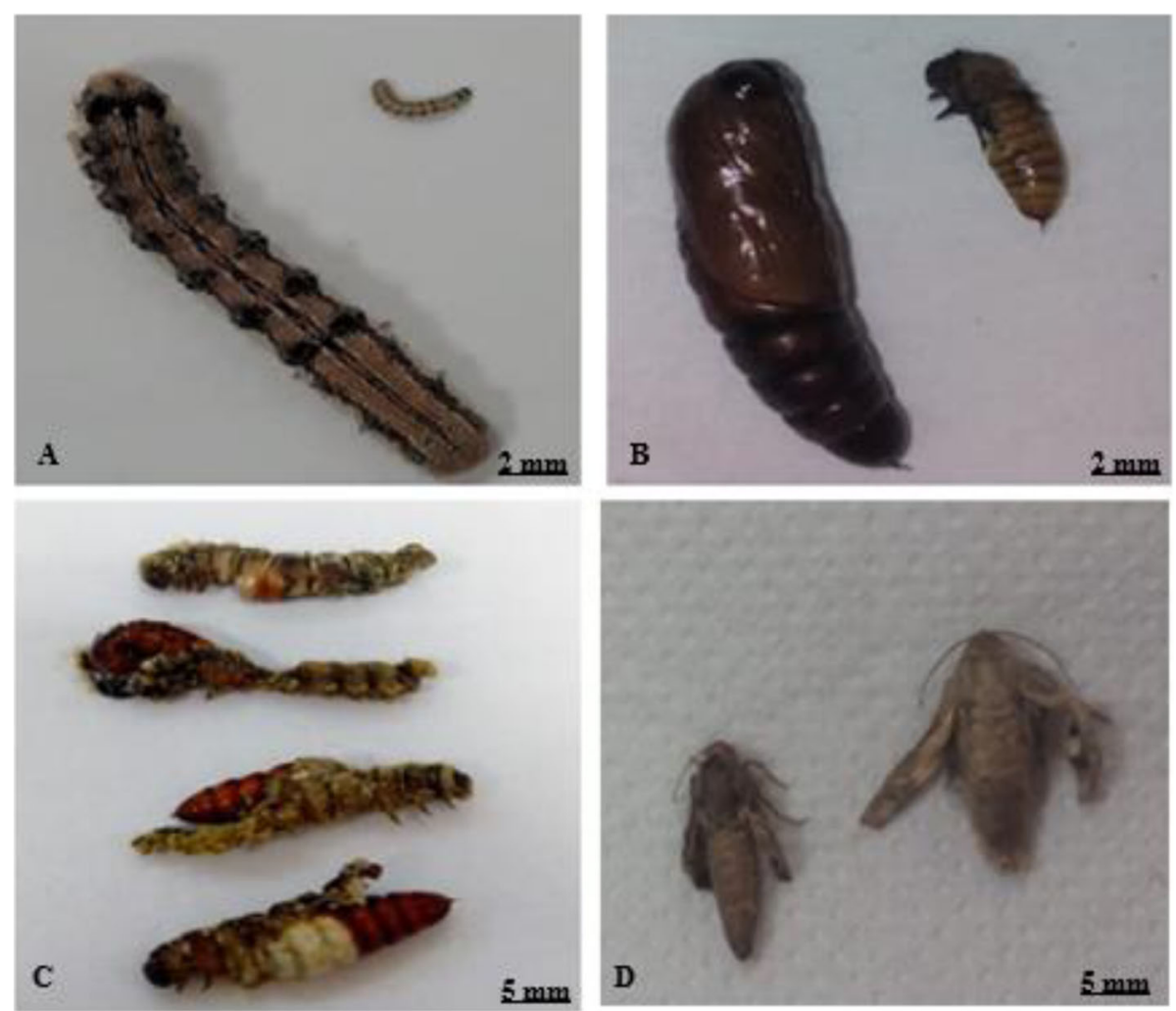

Fig. 5 Morphological abnormalities in Helicoverpa armigera treated with $L C_{50}$ of the fungus B. bassiana (isolate IBCB1363). $\boldsymbol{a}$ Interference in the development of caterpillars shown by the difference in size. $\boldsymbol{b}$ Early pupal phase. $\boldsymbol{c}$ Low pupal weight and size. $\boldsymbol{d}$ Pupal and adult deformations

\section{Effect of the M. anisopliae on biological parameters of $H$. armigera}

The caterpillar weight after 10 days of application of the treatments was lower than that in the control for all treatments. The pre-pupal and pupal weights of the
ESALQ 860 and ESALQ 1051 isolates differed than the control, but were similar to each other. The IBCB 425 isolate did not differ from the control, but differed from the other isolates. The effect of the treatments on the sex ratio was non-significant (Table 5).

Table 5 Sex ratio, number of eggs per female, egg viability, caterpillar weight, pre-pup weight (g), and pupa weight (g) of Helicoverpa armigera treated with Beauveria bassiana and Metarhizium anisopliae

\begin{tabular}{llllll}
\hline Treatments & Sex ratio & Egg viability (\%) & 10th day weight & Pre-pupal weight & Pupa weight \\
\hline Beauveria bassiana & & & & & \\
ARSEF 1149 & 0.55 & $95.87 \pm 0.95 \mathrm{a}$ & $0.10 \pm 0.01 \mathrm{~b}$ & $0.36 \pm 0.01 \mathrm{a}$ & $0.31 \pm 0.00 \mathrm{a}$ \\
ESALQ 1288 & 0.52 & $92.23 \pm 0.86 \mathrm{a}$ & $0.09 \pm 0.01 \mathrm{~b}$ & $0.36 \pm 0.01 \mathrm{a}$ & $0.30 \pm 0.00 \mathrm{a}$ \\
IBCB 36 & 0.50 & $95.16 \pm 0.98 \mathrm{a}$ & $0.07 \pm 0.00 \mathrm{~b}$ & $0.31 \pm 0.01 \mathrm{a}$ & $0.32 \pm 0.01 \mathrm{a}$ \\
IBCB 170 & 0.41 & $83.09 \pm 0.78 \mathrm{~b}$ & $0.09 \pm 0.01 \mathrm{~b}$ & $0.36 \pm 0.01 \mathrm{a}$ & $0.33 \pm 0.00 \mathrm{a}$ \\
IBCB 1363 & 0.40 & $75.24 \pm 0.72 \mathrm{c}$ & $0.07 \pm 0.00 \mathrm{~b}$ & $0.21 \pm 0.01 \mathrm{~b}$ & $0.20 \pm 0.01 \mathrm{~b}$ \\
Control & 0.50 & $96.36 \pm 0.65 \mathrm{a}$ & $0.26 \pm 0.01 \mathrm{a}$ & $0.33 \pm 0.02 \mathrm{a}$ & $0.32 \pm 0.01 \mathrm{a}$ \\
Metarhizium anisopliae & & & & & $0.31 \pm 0.02 \mathrm{a}$ \\
IBCB 425 & 0.50 & $60.14 \pm 0.69 \mathrm{c}$ & $0.07 \pm 0.01 \mathrm{bc}$ & $0.22 \pm 0.01 \mathrm{~b}$ & $0.32 \pm 0.01 \mathrm{a}$ \\
ESALQ 860 & 0.43 & $86.83 \pm 0.41 \mathrm{~b}$ & $0.08 \pm 0.01 \mathrm{bd}$ & $0.01 \mathrm{~b}$ \\
ESALQ 1051 & 0.41 & $93.56 \pm 0.58 \mathrm{a}$ & $0.09 \pm 0.00 \mathrm{bd}$ & $0.22 \pm 0.02 \mathrm{~b}$ & $0.25 \pm 0.01 \mathrm{~b}$ \\
Control & 0.50 & $97.39 \pm 0.65 \mathrm{a}$ & $0.21 \pm 0.01 \mathrm{a}$ & $0.36 \pm 0.01 \mathrm{a}$ & $0.35 \pm 0.00 \mathrm{a}$ \\
\hline
\end{tabular}

Means ( \pm standard error) followed by the same letter in the columns are not significantly different by Tukey's test at $5 \%$ significance level $(p<0.05)$ 
Table 6 Mean parameters ( \pm SE) of the Helicoverpa armigera life table subjected to different isolates of the fungi Beauveria bassiana and Metarhizium anisopliae over one generation at $25 \pm 1{ }^{\circ} \mathrm{C}$ and $70 \pm 10 \% \mathrm{RH}$

\begin{tabular}{|c|c|c|c|c|c|}
\hline \multirow{3}{*}{ Treatments } & \multicolumn{5}{|c|}{ Population parameters } \\
\hline & \multicolumn{5}{|c|}{ Beauveria bassiana } \\
\hline & $T$ (daya) & $R_{\circ}$ & $r\left(\right.$ day $\left.^{-1}\right)$ & $\lambda\left(\right.$ day $\left.^{-1}\right)$ & GRR \\
\hline ARSEF 1149 & $40.03 \pm 0.15 b$ & $97.34 \pm 15.88 b$ & $0.114 \pm 0.00 b$ & $1.12 \pm 0.00 \mathrm{a}$ & $97.34 \pm 15.88 c$ \\
\hline ESALQ 1288 & $51.07 \pm 0.32 \mathrm{a}$ & $83.12 \pm 16.41 \mathrm{C}$ & $0.086 \pm 0.00 c$ & $1.09 \pm 0.00 \mathrm{a}$ & $87.05 \pm 18.01 \mathrm{~d}$ \\
\hline IBCB 36 & $31.93 \pm 0.11 c$ & $70.14 \pm 17.24 d$ & $0.133 \pm 0.00 a$ & $1.14 \pm 0.00 \mathrm{a}$ & $78.39 \pm 19.01 \mathrm{e}$ \\
\hline IBCB 170 & $42.76 \pm 0.14 b$ & $63.58 \pm 19.39 e$ & $0.097 \pm 0.00 c$ & $1.10 \pm 0.00 \mathrm{a}$ & $146.44 \pm 38.82 b$ \\
\hline IBCB 1363 & $40.15 \pm 0.24 b$ & $98.48 \pm 24.85 b$ & $0.114 \pm 0.00 b$ & $1.12 \pm 0.00 \mathrm{a}$ & $148.94 \pm 36.55 b$ \\
\hline Control & $41.29 \pm 0.16 b$ & $216.58 \pm 35.01 \mathrm{a}$ & $0.130 \pm 0.00 a$ & $1.11 \pm 0.00 \mathrm{a}$ & $248.61 \pm 44.39 a$ \\
\hline \multirow[t]{2}{*}{ Treatments } & \multicolumn{5}{|c|}{ Metarhizium anisopliae } \\
\hline & $T$ (day) & $R_{\circ}$ & $r\left(\right.$ day $\left.^{-1}\right)$ & $\lambda\left(\right.$ day $\left.^{-1}\right)$ & GRR \\
\hline IBCB 425 & $43.63 \pm 0.28 c$ & $172.84 \pm 34.50 \mathrm{~b}$ & $0.118 \pm 0.00 b$ & $1.13 \pm 0.00 \mathrm{a}$ & $205.23 \pm 42.71 b$ \\
\hline ESALQ 860 & $51.05 \pm 0.28 b$ & $127.24 \pm 22.23 c$ & $0.094 \pm 0.00 c$ & $1.09 \pm 0.00 \mathrm{a}$ & $136.45 \pm 25.41 c$ \\
\hline ESALQ 1051 & $61.05 \pm 0.33 \mathrm{a}$ & $92.48 \pm 21.09 \mathrm{~d}$ & $0.074 \pm 0.00 \mathrm{~d}$ & $1.07 \pm 0.00 \mathrm{a}$ & $113.35 \pm 26.16 d$ \\
\hline Control & $41.29 \pm 0.16 c$ & $216.58 \pm 35.01 \mathrm{a}$ & $0.130 \pm 0.00 a$ & $1.11 \pm 0.00 \mathrm{a}$ & $248.61 \pm 44.39 a$ \\
\hline
\end{tabular}

The data of each parameter were calculated using 100,000 bootstraps. Means followed by the same letters are not different by the paired bootstrap test ( $p<$ 0.05). $T$ average duration of one generation (days); $R_{\mathrm{o}}$ net reproduction rate, $r$ intrinsic rate of increase (day 1 ), $\lambda$ finite rate of increase (day ${ }^{-1}$ )

\section{Life table}

The average generation time $(T)$ of $H$. armigera treated with the B. bassiana isolates ARSEF 1149, reached 40.03 days, and ESALQ 1288 (51.07 days) had a significant difference than the control (41.29 days). The net reproduction rate $\left(R_{\mathrm{o}}\right)$ in the control was 216.58 . It was $2.5 \%$ higher than those in the treatments (Table 6).

The intrinsic rate of increase $(r)$ in the control $(0.130$ day $^{-1}$ ) was significantly higher than those at 4 isolates. Only the isolate IBCB 36 showed no difference than the control. The finite rate of increase $(\lambda)$ in the treatments showed a non-significant difference. The gross reproduction rate (GRR) of $H$. armigera in the control (248.61) was higher than those of all isolates tested, showing a significant difference between females at all treatments (Table 6). All M. anisopliae isolates affected the average generation time $(T)$, which was significantly higher than in the control. The net reproduction rate $\left(R_{\mathrm{o}}\right)$ of the treatments was lower than that in the control. The intrinsic rate of increase $(r)$ in the control (0.130) was higher than that in the treatments, but the finite rate of increase $(\lambda)$ showed no difference for any isolate tested. The gross reproduction rate (GRR) in the control (248.61) was higher than that in the treatments IBCB 425 (205.23), ESALQ 860 (136.45), and ESALQ 1051 (113.35) (Table 6).

Beauveria bassiana and $M$. anisopliae affected the biological parameters $T, R_{\mathrm{o}}, r, \lambda$, and GRR of $H$. armigera, but with lower intensity than the control, and depending on the isolate. The net reproduction rate $\left(R_{\mathrm{o}}\right)$ was significantly lower than in the control, promoting effects that will compromise the subsequent generation, acting effectively in the control of the species.

\section{Conclusion}

The use of sublethal concentrations of the fungi isolates of $M$. anisopliae and B. bassiana resulted in an adverse effect on the biology of $H$. armigera. The high number of promising fungus isolates increases the probability of an effective control of these species by these fungi and reduction in the development of resistance in $H$. armigera populations.

\section{Abbreviations}

Bt: Bacillus thuringiensis; ARSEF: Collection of Entomopathogenic Fungal Cultures; ESALQ: School of Agriculture Luiz de Queiroz; IBCB: Biological Institute of Campinas; PDA: Potato Dextrose Agar; LC: Lethal concentration; APOP: Period from the appearance of adults to the first oviposition; TPOP: Total pre-oviposition; $r$ : Population growth rate; $\lambda$ : Finite population growth rate; $R_{0}$ : Net reproduction rate; T: Average generation duration; GRR: Reproduction rate; Sxj: Age-specific survival rate; Fxj: Age-specific fertility of the stage; $m x$ : Age-specific fertility; MTD: Mortality; LOGOV: Egg stage duration; LOGLA: Caterpillar longevity; PRPU: Pre-pupa longevity; PUPA: Pupa stage duration; LOGTO: Total longevity; FECU: Fertility; OVI: Oviposition; PC: Principal components

\section{Acknowledgements}

The authors thank the Coordination for the Improvement of Higher Education Personnel - Brazil (CAPES) for granting the scholarship; the State University, Jaboticabal, São Paulo, for the infrastructure; the Collection of Entomopathogenic Fungal Cultures (ARSEF-USDA) of the School of Agriculture Luiz de Queiroz (ESALQ, Piracicaba, SP, Brazil); and the Campinas Biological Institute (IBCB, Campinas, SP, Brazil). This study was partly financed by the CAPES (Financial Code 001).

\section{Authors' contributions}

TDS: Master's student responsible for the project, participated in the planning and execution of bioassays, data analysis, and writing of the 
manuscript. FOF: Assisted in the setup and evaluation of experiments in the laboratory and in the analysis of the data. ACS: Assisted in the setup of the experiments in the laboratory. RAP: Project supervisor; guided the data collection and reviewed the manuscript. All authors have read and approved the manuscript.

\section{Funding}

The work was financed by the São Paulo State Research Support Foundation (FAPESP, grant $n^{\circ} 2018$ / 21089-3), which subsidized all purchases of inputs and materials used, together with the support of CAPES for the aid to the student scholarship (Financial Code 001).

\section{Availability of data and materials}

All data of the study have been presented in the manuscript, and highquality and grade materials were used in this study.

\section{Ethics approval and consent to participate} Not applicable.

\section{Consent for publication}

Not applicable.

\section{Competing interests}

The authors declare that they have no competing interests.

\section{Received: 16 July 2020 Accepted: 24 September 2020}

Published online: 23 November 2020

\section{References}

Ahmad S, Ansari MS (2013) Acute toxicity and sub-lethal effects of a pyrethroid (Cypermethrin) on survival, development and fitness of Helicoverpa armigera. Archives of Phytopathology and Plant Protection 46:1726-1739

Alves, SB (1998) Controle microbiano. FEALQ, Piracicaba, São Paulo, 1163p.

Amiri-besheli B, Khambay B, Cameron S, Deadman ML, Butt TM (2000) Inter and intra specific variation in destruxin production by insect pathogenic Metarhizium spp., and its significance to pathogenesis. Mycological Research 104:447-452. https://doi.org/10.1017/S095375629900146X

Arthurs S, Thomas MB (2000) Effects of a mycoinsecticide on feeding and fecundity of the Brown locust Locustana pardalina. Biocontrol Science Technology 10:321-329 https://doi.org/10.1080/09583150050044592

Botelho RZ, Alves PAB, Colonhez PA, Zucchi RMI, Delalibera II (2019) Metarhizium species in soil from Brazilian biomes: a study of diversity, distribution, and association with natural and agricultural environments. Fungal Ecology 41: 289-300 https://doi.org/10.1016/j.funeco.2019.07.004

Challa MM, Sanivada SK, Koduru UD (2013) Total soluble protein profiles of Beauveria bassiana and their relationship with virulence against Helicoverpa armigera. Biocontrol Science and Technology 23:1169-1185 https://doi.org/ 10.1080/09583157.2013.82247

Chi H (1988) Life-table analysis incorporating both sexes and variable development rate among individuals. Journal Environ Entomol 17:26-34 https://doi.org/10.1093/ee/17.1.26

Chi H (2016) TWOSEX-MSChart: a computer program for the age-stage, two-sex life table analysis. http://140.120.197 .173/Ecology/Download/Twos exMSChart. zip acessado 10 setembro 2019

Chi H, Liu H (1985) Two new method for the study of insect population ecology. Bulletin 24:225-240

Gibson DM, Donzelli BG, Krasnoff SB, Keyhani NO (2014) Discovering the secondary metabolite potential encoded within entomopathogenic fungi. Natural Product Reports 31:1287-1305. http://dx.doi.org. https://doi.org/10. 1039/c4np00054d

Goettel MS, Elienberg J, Glare T (2010) Entomopathogenic fungi and their role in regulation of insect populations. In: Laurence IG, Sarjeet SG (Eds). Insect control: biological and synthetic Agents 113:206-2014 https://doi.org/10. 1590/0074-02760170369

Greene GL, Leppla NC, Dickerson WA (1976) Velvetbean caterpillar: a rearing procedure and artificial diet. Journal of Economic Entomology 69:497-488 https://doi.org/10.1093/jee/69.4.487

Hassani M (2000) Development and proving of biocontrol methods based on Bacillus thuringiensis and entomopathogenic fungi against the cotton pests Spodoptera littoralis, Helicoverpa armigera (Lepidoptera: Noctuidae) and Aphis gossypii (Homoptera: Aphididae). 130 f. TESE. University of Giessen, Germany.
Jaronski ST (2007) Soil esology of the entomopathogenic Ascomycetes: a critical examination of what we (think) we know. In: Ekesi S, Maniania NK Use of Entomopathogenic Fungi in Biological. Pest Management 1:91-144 https:// doi.org/10.1016/j.jip.2016.05.008

Jarrahi A, Safavi SA (2016) Fitness costs to Helicoverpa armigera after exposure to sub-lethal concentrations of Metarhizium anisopliae sensu lato: study on F1 generation. Journal of Invertebrate Pathology 138:50-56 https://doi.org/10. 1016/j.jip.2016.05.008

Kalvnadi E, Mirmoayedi A, Alizadeh M, Pourian HR (2018) Sub-lethal concentrations of the entomopathogenic fungus, Beauveria bassiana increase fitness costs of Helicoverpa armigera (Lepidoptera: Noctuidae) offspring. Journal of Invertebrate Pathology 158:32-42. https://doi.org/10.1016/j.jip. 2018.08.012

Kaur, S.; Kaur, H.P.; Kaur, K.; Kaur, A. Effect of different concentrations of Beauveria bassiana on development and reproductive potential of Spodoptera litura (Fabricius). Journal of Biopesticides, v. 4, p. 161-168, 2011

Lacey AW (2017) Microbial control insect and mite pests. FNP: Academic Press, $446 p$.

Leora Software, polo-pc (1987) a user's guide to Probit or Logit analysis. Leora Software, Berkeley, CA.

Levy SM, Falleiros AMF, Gregório EA, Arrebola NR, Toledo LA (2004) The larval midgut of Anticarsia gemmatalis (Hübner) (Lepidoptera: Noctuidae): light and electron microscopy studies of the epithelial cells. Brazilian Journal of Biology 64:633-638 https://doi.org/10.1590/S1519-69842004000400010

Molnar I, Gibson DM, Krasnoff SB (2010) Secondary metabolites from entomopathogenic Hypocrealean fungi. Natural Product Reports 27:12411275. http://dx.doi.org: 10.1039/c001459c

Mora MAE, Rouws CRJ, Fraga EM (2016) Occurrence of entomopathogenic fungi in Atlantic forest soils. Microbiology Descubray 4:2052-6180. http://dx.doi.10. 7243/2052-6180-4-1

Nguyen NTH, Borgemeister C, Poehling MH, Zimmermann G (2007) Laboratory investigations on the potential of entomopathogenic fungi for biocontrol of Helicoverpa armigera (Lepidoptera: Noctuidae) larvae and pupae. Biocontrol Science and Technology 17: 853-864

Peroni N, Hernández M (2011) Ecologia de Populações e Comunidades. ISCED (ED), 185p

Qu S, Wang S (2018) Interaction of entomopathogenic fungi with the host immune system. Developmental e Comparative Immunology 83:96-103 https://doi.org/10.1016/j.dci.2018.01.010

R Core Team (2018). R: a language and environment for statistical computing. $R$ Foundation for Statistical Computing, Vienna, Austria https://www.R-project. org/.

Renwrantz L (1986) Lectins in molluscs and arthropods: their occurrence origin and roles in immunity. In: Lackie, AM (Ed). Immunity mechanisms in invertebrate vectors $150 \mathrm{p}$

Rezende LM, Zanardo ABR, Lopes MS, Delalibera JRI, Rehner AS (2015) Phylogenetic diversity of Brazilian Metarhizium associated with sugarcane agriculture. BioControl 60:495-505. https://doi.org/10.1007/s10526-015-9656-5

Rohlfs M, Churchill ACL (2011) Fungal secondary metabolites as modulators of interactions with insects and other arthropods. Fungal Genetics and Biology 48:23-34. https://doi.org/10.1016/j.fgb.2010.08.008

Tay WT, Soria FM, Walsh T, Thomazoni D, Silvie P, Behere TG, Anderson C (2013) A brave new world for an old-world pest: Helicoverpa armigera (Lepidoptera: Noctuidae) in Brazil. Plos One 8:134-138 https://doi.org/10.1371/journal.pone. 0080134

Wang D, Qiu X, Ren X, Niu F, Wang K (2009) Resistance selection and biochemical characterization of spinosad resistance in Helicoverpa armigera (Hübner) (Lepidoptera: Noctuidae). Pesticide Biochemistry and Physiology 95: 90-94 https://doi.org/10.1016/j.pestbp.2009.07.003

Wang Z, Wilhelmsson C, HyrsI P, Loof TG, Dobes P, Klupp M, Loseva O, Morgelin M, Ikle J, Cripps RM, Herwald H, Theopold U (2010) Pathogen entrapment by transglutaminase-a conserved early innate immune mechanism. PLoS Pathog 6:1-10 https://doi.org/10.1371/journal.ppat.1000763

Wu S, Youngman RR, Kok LT, Laub CA, Pfeiffer DG (2014) Interaction between entomopathogenic nematodes and entomopathogenic fungi applied to third instar southern masked chafer white grubs, Cyclocephala lurida (Coleoptera: Scarabaeidae), under laboratory and greenhouse conditions. Biological Control, 76:65-73. doi:10.1016/j.biocontrol.2014.05.002

Yang Y, Li Y, Wu Y (2013) Current status of insecticide resistance in Helicoverpa armigera after 15 years of Bt cotton planting in China. Journal of Econmic Entomology 1061:375-381. https://doi.org/10.1603/ec12286 
Zenker MM, Specht A, Corseuil E (2007) Estágios imaturos de Spodoptera cosmioides (Walker) (Lepidoptera, Noctuidae). Revista Brasileira Zoologia 24: 99-107 https://doi.org/10.1590/S0101-81752007000100013

Zimmermann G (2007) Review on safety of the entomopathogenic fungus Metarhizium anisopliae. Biocontrol Science and technology 17:879-920 https://doi.org/10.1080/09583150701593963

\section{Publisher's Note}

Springer Nature remains neutral with regard to jurisdictional claims in published maps and institutional affiliations.

Submit your manuscript to a SpringerOpen ${ }^{\circ}$ journal and benefit from:

- Convenient online submission

- Rigorous peer review

- Open access: articles freely available online

- High visibility within the field

- Retaining the copyright to your article

Submit your next manuscript at $\boldsymbol{\sim}$ springeropen.com 